\title{
Baseline Study of Reproductive Performances of Indigenous Rams in Bangladesh
}

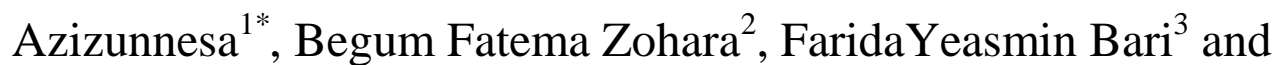 \\ Md. Golam Shahi Alam ${ }^{3}$ \\ ${ }^{I}$ Department of Medicine and Surgery, Faculty of Veterinary Medicine Chittagong Veterinary and Animal \\ Sciences University, Khulshi, Chittagong-4202, Bangladesh. \\ ${ }^{2}$ Department of Medicine, Surgery and Obstetrics, Faculty of Veterinary \& Animal Science Hajee Mohammad \\ Danesh Science \& Technology University Basherhat, Dinajpur-5200, Bangladesh \\ ${ }^{3}$ Department of Surgery and Obstetrics, Faculty of Veterinary Science Bangladesh Agricultural University, \\ Mymensingh-2202, Bangladesh.
}

\begin{abstract}
Selection of breeding rams would be the prerequisite for getting better fertility can be accomplished through selecting some important reproductive traits. Cited information regarding reproductive performances of ram necessary for breeding programme is absent in our country (if available). The objective of the present study was to measure the reproductive performances of indigenous rams. Ram lambs were selected on the basis of indigenous characteristics. They were maintained on natural grazing with lump some amount of concentrate. Body weight and growth rate, scrotal circumference and its growth rate, BCS and libido index were measured weekly. Age, body weight, BCS and scrotal circumference at puberty were recorded. Semen was collected once a weak using artificial vagina and subjected for evaluation of volume, color, density, mass motility, concentration, motility, functional integrity and normal morphology of spermatozoa. The body weight, BCS, scrotal circumference, growth rate of body weight and scrotal circumference were $20.8 \pm 0.6(\mathrm{~kg}), 3.6 \pm 0.1$, $22.8 \pm 0.2(\mathrm{~cm}), 17.0 \pm 0.6(\mathrm{~g} / \mathrm{d}), 1.6 \pm 0.2(\mathrm{~mm} / 15 \mathrm{~d})$, respectively. Age, body weight, BCS and scrotal circumferences at puberty were $6.8 \pm 0.1$ (months), $10.0 \pm 0.4(\mathrm{~kg}), 3.2 \pm 0.1,18.6 \pm 0.7(\mathrm{~cm})$, respectively. The volume, density, mass motility, concentration were $1.2 \pm 0.0 \mathrm{ml}, 2.9 \pm 0.0,4.3 \pm 0.0$ and $4.1 \pm 0.7 \times 10^{9}$, respectively. The rate of motility: $89.0 \pm 0.2,72.4 \pm 0.2,62.0 \pm 0.6$, viability: $91.8 \pm 0.1,75.6 \pm 0.2,64.8 \pm 0.6$, functional integrity: $87.3 \pm 0.2,69.1 \pm 0.2$, $50.2 \pm 0.5$ and normal spermatozoa were $94.0 \pm 0.1,77.3 \pm 0.1$ and $75.0 \pm 0.2$ in fresh, chilled and frozen semen, respectively.
\end{abstract}

Keywords: Indigenous ram, reproductive characters, semen quality

\section{Introduction}

Sheep may contribute a significant amount in the protein content and income generation to the people of Bangladesh since they are easy to rear and more resistance to infectious diseases compared with goat. There are 3.12 million sheep in Bangladesh [1]. The small non-descript indigenous sheep probably originated from southeastern sub-tropical region's. In our country sheep is generally managed under rural condition. They are sparsely distributed throughout some specific areas within the country [2]. Recently the farmers are aware of their benefits and have great interest to increase the sheep production through farming. However, there is scarcity of breeding rams and absence of cited information regarding reproductive performances required for breeding purpose. The genetic potential and productivity of goats and sheep are deteriorating due to indiscriminate type of breeding. This may be minimized by providing sound breeding knowledge to the breeder [3]. The reproductive performances are influenced by several factors [4]. Selection of young rams for fertility can be accomplished through selecting some important reproductive traits such as age at puberty, body condition score, body growth rate, scrotal circumference, scrotal growth rate and semen quality [5]. There was a positive relationship between body weight, scrotal circumference and testicular weight [6] and in general increased testicular weight lead to produce good quality semen [7].

As mentioned above there is paucity of information regarding reproductive performances, quality of semen for breeding and AI. Hence, the sheep is producing without any improvement in any economic trait resulting in significant economic loss of the country. Limited studies were undertaken to observe the productive and reproductive performances of ewes in Bangladesh [8]. However, the same attention was not offered to indigenous ram. When the ewes are in estrus the farmers desperately looks for the ram for service and become disappointed both by scarcity and high quality ram. It is urgent to select sound rams for breeding programme to speed up the production of economic traits with high genetic merit. Therefore, a comprehensive study was designed to observe the baseline study of reproductive performances of indigenous ram. 


\subsection{Study area and period}

\section{Materials and Methods}

The study was conducted at the Department of surgery and Obstetrics, Bangladesh Agricultural University, Mymensingh-2202 during the period from May 2011 to April 2013. The research units are located on N 24.73 and $\mathrm{E} 90.44$ latitude and longitude, respectively and elevated $9 \mathrm{~m}$ above sea level. The area receives on average $174 \mathrm{~mm}$ of rainfall. Mean annual minimum and maximum temperatures experienced at the site are 16.46 and $29.13^{\circ} \mathrm{C}$, respectively.

\subsection{Experimental animals and management}

Fourteen ram lambs 4-5 months old, selected and purchased from the local market on the basis of indigenous or local characters and kept under semi-intensive condition at the Department of Surgery and Obstetrics, Faculty of Veterinary Science, Bangladesh Agricultural University, Mymensingh, Bangladesh. After acclimatization, rams were dewormed and vaccinated against rabies and tetanus. Rams were maintained on natural grazing. Lump some amount of concentrates consisted of wheat bran (50\%), crushed maize (25\%), soy bean meal $(20 \%)$, fish meal (1\%), dicalcium phosphate (DCP) powder (2\%), vitamin mineral premix $(0.5 \%)$, and salt $(1.5 \%)$ was supplied to the rams along with grazing. Rams were supplied ad libitum drinking water.

\subsection{Experimental design}

Body weight $(\mathrm{kg})$, scrotal circumference $(\mathrm{cm})$ and their growth rate were measured weekly. Body condition score (BCS) was measured by palpating lumber region as like other small ruminants and recorded in a score (1-5 with 0.5 increment) [9]. Scrotal circumference $(\mathrm{cm})$ was measured by passing a flexible tape around the scrotum (both testes at the same level) at the point of maximum circumference. Age (months), BCS, body weight $(\mathrm{kg})$ and scrotal circumference $(\mathrm{cm})$ at puberty were calculated. Puberty was determined as the age when the ejaculate contained $>50 \times 10^{6}$ spermatozoa, sufficient to accomplish fertilization [10]. Libido index was graded from 0 to $3 ; 0$ no desire to move towards a teaser ewe. 1 very reluctant to reach the teaser. 2 willingly moved towards the teaser. 3 moved towards the ewe in an uncontrolled manner. Other sexual behaviours were recorded during the whole experimental period.

\subsection{Semen Collection, preservation and evaluation}

Semen was collected by artificial vagina once a week. All glassware for collection and handling were cleaned and sterilized using high-pressure steam, dried and warmed at $35^{\circ} \mathrm{C}$. After ejaculation, the tube was immediately placed in a bath at $37^{\circ} \mathrm{C}$. The volume of semen was measured directly from the graduated collecting tube. Colour was estimated by visual inspection and density was scored by making the tubes slant with score range 0-5. Microscopic examination was performed under phase contrast microscope (Gallenhamp, No. 82TT8, Cat No. M/6-200-H HZ 60, England). Mass motility was estimated by assessment of wave motion of fresh undiluted semen under microscope 10x with 0-5 score. The concentration of spermatozoa was counted by placing a drop of diluted (1:400) semen on haemocytometer. To evaluate sperm motility, $5 \mu$ of diluted semen was placed on a warmed $\left(37^{\circ} \mathrm{C}\right)$ slide, covered by a cover slip and examined $(400 \mathrm{x})$. Semen was diluted (1:10) with tris based diluents and was stored at chilling $\left(5-8^{\circ} \mathrm{C}\right)$ for up to $48 \mathrm{~h}$ and freezing method accordingly.

\subsection{Morphological evaluation}

Eosin-nigrosin stain was used to determine the viability of spermatozoa. Small drop of semen and one drop of eosin-nigrosin stain were placed on a clean slide and mixed with a clean stick, a thin smear was made, dried in air and examined under microscope (400x). At least 200 spermatozoa were examined from each smear to calculate the percentages of live spermatozoa. Hypo-osmotic swelling (HOST) test was used to measure the proportion of spermatozoa that swelled, giving an estimate of the proportion with functional integrated spermatozoa. Normal (acrosome, midpiece and tail) rate of spermatozoa were evaluated using Spermac stain ${ }^{\circledR}$ (Minitube, Box 152, Wellington, 7654, South Africa) (400-1000x). Before evaluation, semen was taken to warm up and thawed at 39 to 40 for 14 second for chilled and frozen, respectively.

\subsection{Statistical analysis}

Data generated and statistical analyses were carried out for mean \pm SEM in each particular parameter. Data were analyzed using SPSS 17.0 computer program package (SPSS, USA).

\subsection{Reproductive characters}

\section{Results}

The body weight, scrotal circumference and body condition score of selected ram lambs were $8.4 \pm 0.4(\mathrm{~kg}), 14.8 \pm 0.8(\mathrm{~cm})$ and $3.1 \pm 0.0$. The same parameters for mature rams were $20.8 \pm 0.6(\mathrm{~kg}), 22.8 \pm 0.2(\mathrm{~cm})$ and 3.6 \pm 0.1 , respectively. The growth rate of body weight and scrotal circumference was $17.0 \pm 0.6(\mathrm{~g} / \mathrm{d})$ and 
$1.6 \pm 0.2(\mathrm{~mm} / 15 \mathrm{~d})$, respectively. Age, BCS, body weight and scrotal circumference at puberty were $6.8 \pm 0.1$ (months), $3.2 \pm 0.3,10.0 \pm 0.4(\mathrm{~kg})$, and $18.6 \pm 0.7(\mathrm{~cm})$, respectively. The mean libido index was $2.6 \pm 0.1$ (Table 1).

Table 1. Reproductive parameters of indigenous rams

\begin{tabular}{lll}
\hline Parameters & Mean \pm SEM & Range \\
\hline Selected ram lambs body weight $(\mathrm{kg})$ & $8.4 \pm 0.4$ & $6.5-11.5$ \\
Mature body weight $(\mathrm{kg})$ & $20.8 \pm 0.6$ & $17.5-25$ \\
Body growth rate $(\mathrm{g}) / \mathrm{d}$ & $17.0 \pm 0.6$ & $15.1-21.9$ \\
Selected ram lambs body condition score $(1-5)$ & $3.1 \pm 0.0$ & $3-3.5$ \\
Mature body condition score $(1-5)$ & $3.6 \pm 0.1$ & $3-4$ \\
Selected ram lambs scrotal circumference $(\mathrm{cm})$ & $14.8 \pm 0.8$ & $10.5-18.5$ \\
Mature scrotal circumference $(\mathrm{cm})$ & $22.8 \pm 0.2$ & $21-24$ \\
Scrotal growth rate $(\mathrm{mm} / 15 \mathrm{~d})$ & $1.6 \pm 0.2$ & $0.8-2.5$ \\
Age at puberty (months) & $6.8 \pm 0.1$ & $6-7.5$ \\
Body condition score $(1-5)$ at puberty & $3.2 \pm 0.3$ & $3-3.5$ \\
Body weight at puberty $(\mathrm{kg})$ & $10.0 \pm 0.4$ & $8-12.7$ \\
Scrotal circumference $(\mathrm{cm})$ at puberty & $18.6 \pm 0.7$ & $13-21.7$ \\
Libido index $(0-3)$ & $2.6 \pm 0.1$ & $2-3$ \\
\hline
\end{tabular}

Values are presented as mean $\pm \mathrm{SEM}$

The investigating others sexual behaviours in rams are presented in Table 2

Table 2. Others sexual behaviours

\begin{tabular}{|c|c|}
\hline Parameters & Characters \\
\hline $\begin{array}{l}\text { Libido } \\
\text { characteristics }\end{array}$ & $\begin{array}{l}\text { Neck outstretched and head held horizontally (searching female), flehmen, } \\
\text { sniffing and licking of ewe's vulva, nudging ewe, repeated dorsal elevation of } \\
\text { scrotum, penile protrusion with no dribbling of seminal fluid. }\end{array}$ \\
\hline $\begin{array}{l}\text { Duration } \\
\text { copulation }\end{array}$ & Very short period. \\
\hline $\begin{array}{l}\text { Ejaculatory } \\
\text { behavior }\end{array}$ & $\begin{array}{l}\text { Before ejaculation several times of mount have been observed however } \\
\text { sometimes ejaculate take place by } 1^{\text {st }} \text { mount, homosexual behaviours was } \\
\text { observed. }\end{array}$ \\
\hline $\begin{array}{l}\text { Mating } \\
\text { characters }\end{array}$ & $\begin{array}{l}\text { Serious fighting with other male to mate female, dominance effects and gargling, } \\
\text { rams normally display agonistic behavior when introduced into the ewe flock. }\end{array}$ \\
\hline
\end{tabular}

\subsection{Indigenous ram semen characters}

The colour of fresh semen was creamy white immediately after collection. The volume, density, mass motility and concentration of semen were $1.2 \pm 0.0 \mathrm{ml}, 2.9 \pm 0.0,4.3 \pm 0.0$ and $4.5 \pm 0.1 \times 10^{9} / \mathrm{ml}$, respectively. The rate of motility, viability, functional integrity and normal morphology was $89.0 \pm 0.2,91.8 \pm 0.1,87.3 \pm 0.2$ and $94.0 \pm 0.1$ in fresh semen while those of chilled semen were $72.4 \pm 0.2,75.6 \pm 0.2,69.1 \pm 0.1$ and $77.3 \pm 0.1$, respectively. However, the rate of motility, viability, functional integrity and normal morphology of post thawed semen were $62.0 \pm 0.6,64.8 \pm 0.6,50.2 \pm 0.5$ and $75.0 \pm 0.2$, respectively (Table 3 ).

Table 2. Quality of indigenous ram semen

\begin{tabular}{llll}
\hline Parameters & & Mean \pm SEM & Range \\
\hline Colour & & Creamy white & - \\
Volume (ml) & & $1.2 \pm 0.0$ & $0.2-1.8$ \\
Density (0-5) & & $2.9 \pm 0.0$ & $2-4$ \\
Concentration $\left(\mathrm{x} 10^{9}\right)$ & & $4.5 \pm 0.1$ & $2-8.9$ \\
Mass motility (0-5) & & $4.1 \pm 0.0$ & $2.5-5$ \\
& Fresh & $89.0 \pm 0.2$ & $80-95$ \\
Motility & Chilled after 48h & $72.4 \pm 0.2$ & $58-85$ \\
& Post thawed & $62.0 \pm 0.6$ & $54-71$ \\
Viability & Fresh & $91.8 \pm 0.1$ & $85-96$ \\
& Chilled after 48h & $75.6 \pm 0.2$ & $58-85$ \\
& Post thawed & $64.8 \pm 0.6$ & $57-75$ \\
HOST test & Fresh & $87.3 \pm 0.2$ & $70-93$ \\
& Chilled after 48h & $69.1 \pm 0.2$ & $55-80$ \\
Normal sperm & Post thawed & $50.2 \pm 0.5$ & $42-57$ \\
& Fresh & $94.0 \pm 0.1$ & $86-98$ \\
& Chilled after 48h & $87.2 \pm 0.1$ & $68-86$ \\
\hline
\end{tabular}

values are presented as mean \pm SEM 


\section{Reproductive characters}

\section{Discussion}

\section{Body weight, scrotal circumference, growth rate, BCS}

The information is available regarding reproductive performances of rams [11]. The present study observed the concerning reproductive performance of native rams in Bangladesh. The mean body weight and scrotal circumference of the present study were $20.8 \pm 0.6 \mathrm{~kg}$ and $22.8 \pm 0.2 \mathrm{~cm}$, respectively which was lower than other breeds in the cited references [12]. They reported the body weight and scrotal circumference of adult Awassi rams were about $79.1 \pm 1.0 \mathrm{~kg}$ and $33.5 \pm 0.8 \mathrm{~cm}$, respectively. It was also showed that the body weight of other exotic sheep breeds like Dorper sheep have live weight of $40 \mathrm{~kg}$. [13]. Live weight of a mature Border Leicester ram would be in the range of $140-175 \mathrm{~kg}$. However, the live weight of sheep in subcontinent countries comparatively lower than others. There was a report on adult ewes body weight was $25.6 \pm 2.9-47.1 \pm 4.4 \mathrm{~kg}$ in Pakistan [14]. The overall mean scrotal circumference was recorded $32.0 \pm 1.2 \mathrm{~cm} \mathrm{[3].} \mathrm{The} \mathrm{mean} \mathrm{growth} \mathrm{rate} \mathrm{of}$ live weight and scrotal circumference of our indigenous rams were also lower than reported by other [15]. This discrimination of body weight [11] and scrotal circumference may be differed depending on different breeds [16], Feeding practice affect the scrotal circumference and scrotal growth rate in ram lambs $(p<0.001)$ [17]. Our experimental rams showed the mean BCS 3.6 \pm 0.1 which is similar to the findings of Tabbaa et al [12] in adult rams. In most cases, healthy sheep and goats should have a BCS of 2.0 to 3.5 and breeding ram should have BCS 3-4 [18].

\section{Age, weight, BCS and scrotal circumference at puberty}

For maintenance of better reproductive management it is need to be known the information about the onset of puberty and sexual maturity [19]. The study revealed that the age at onset of puberty in our indigenous rams is similar to other studied [20]. The mean age and body weight at puberty is comparatively lower but BCS is higher than the findings of Mukasa-Mugerwa and Ezaz [15]. However, the similar condition score (3.3 \pm 0.4$)$ was observed [14] for yearling rams. Although the satisfactory scrotal circumference was $30-36 \mathrm{~cm}$ during the period of 8-14 months age [21], however, our indigenous ram showed $18.6 \pm 0.7 \mathrm{~cm}$ scrotal circumference at pubertal age which was also lower than reported $(29.6 \pm 1.3 \mathrm{~cm})$ in yearling rams [12].

\section{Libido Index}

Our present results on the libido score $(2.6 \pm 0.1)$ of indigenous rams showed to be normal. Snowder et al. [22] reported that the overall mean libido score was $3.5 \pm 0.02$ when the score ranged from 1-6. Rams may exhibit a wide range of libido levels [23]. Day length has an effect on reproduction in male and female. The highest libido, fertility, and semen volume with good quality were observed in late summer and autumn, when the females will allow breeding [24]. Even though the present study was not related to feeding practice however, it was reported that diet has effect on libido. Carbohydrate or protein deficiency may impair libido in males [25]. It was also reported that the supplemented diet had tendency to increased sex drive compared to control though the difference was insignificant $(p>0.05)$ [26].

\section{Other sexual behaviours}

The recorded some other sexual characters in indigenous rams during the experimental period were similar to the findings of Perkins and Roselli [27]. Mounting behavior in rams is accompanied by a series of shallow pelvic thrusts. The rams in this study mounted several times before ejaculation however, it was not exceptional that the rams exhibited ejaculation by $1^{\text {st }}$ mount within very short period: $1-2$ seconds. This type of sexual behavior also showed by Bermant et al. [28] in rams. Rams failed to jump estrous ewes and ejaculates those were transferred from their mother and sisters by 90 days of age and raised in a group with all male. However they were homosexual. A similar result was described by Perkins and Roselli [27]. They noted that 20 to 35 percent of sexually inexperienced yearling rams reared in all male groups were sexually inactive when they were first exposed to estrous females. Fighting was a serious problem among rams. Mature and larger rams were almost always dominated over smaller rams. Sometimes smaller rams were more aggressive and bred more ewes.

\section{Semen characters of indigenous rams Volume, density, mass motility and concentration}

Semen volume is one of the important factors in semen evaluation and reproductive performance in males [29]. The present result regarding the volume of semen in our rams is similar to the finding of others [3] but dissimilar result was also observed [30]. They reported the overall mean volume of semen from Pirlak rams was $1.5 \pm 0.1 \mathrm{ml}$. The quality of semen in native rams was not studied. The typical ram ejaculate was 1 to $2 \mathrm{ml}$ and contains 1 to 5 billion sperm cells [21]. The volume of semen could be varying with the breed, age, and the collection interval. The Suffolk, Walachian and Sumava sheep produce 1.8 $\pm 0.5,1.6 \pm 0.6$ and $1.9 \pm 0.7 \mathrm{ml}$ semen, 
respectively [31]. The mean density was $2.9 \pm 0.0$ and mass motility of semen from this study was $4.3 \pm 0.0$ which was comparatively higher than that reported by others [3,32]. The finding of concentration of spermatozoa $\left(4.1 \pm 0.7 \times 10^{9}\right)$ per $\mathrm{ml}$ was found to be similar with the other result [30]. He recorded that the concentration of spermatozoa was $4.2 \times 10^{9} / \mathrm{ml}$ of Pirlak rams. On the other hand, Ibrahim [33] showed the higher sperm concentration $\left(4.9 .7 \times 10^{9} / \mathrm{ml}\right)$ in rams. Similar observation was also observed [3]. Normal concentration of ram spermatozoa per ml varying from $1.6 \times 10^{9}$ to $6.0 \times 10^{9}$ with an average of $3.6 \times 10^{9}$ [34]. Our result was within the normal range of sperm concentration. Higher the number of sperm $/ \mathrm{ml}$ allow to produce higher number of insemination doses ultimately create opportunity to inseminate larger number of females to inseminate [35]. Sperm production, as well as total number of spermatozoa per ml, can be affected by breed [36] and nature of diet [37].

\section{Motility, viability, functional integrity and normal morphology of spermatozoa}

The proportion of motile spermatozoa for fresh, chilled and post thawed frozen semen was within a standard range as the minimal value of sperm motility for the ram is 60\% [38]. The motile spermatozoa provide strong evidence for sperm maturation. Sperm motility is a fairly reliable indication of the viability of semen [39]. After chilling or freezing the percentages of sperm motility was reduced. The results confirmed the other finding [30] for chilled and [40] for frozen semen.

Determination of $\%$ viable sperm is important in assessing semen for AI. The percent viable spermatozoa in our result comparatively higher than other [30]. He reported the mean proportion of live spermatozoa in Pirlak rams was $92.9 \%$ at $0 \mathrm{~h}$ of observation. Although the preservation decreased the rate of sperm viability from $91.8 \pm 0.1$ to $75.6 \pm 0.2$ when chilled and $64.8 \pm 0.6$ when frozen, however, the rate of viability was within the standard ranged accordingly [41]. The time of preservation damaged the sperm membrane and ultimately cell death [42].

In fresh semen the values for HOST positive spermatozoa in this study is higher than the finding of Juyena [43] reported 76\% HOST positive sperm cell in Padovana rams. In chilled semen, the present result for hypo-osmotic swelling test value is higher than in Pirlak rams semen after chilling. The similar observation was observed in preservation time decrease in the hypo osmotic resistance of spermatozoa [30]. From above discussion it was observed that the rate of functional integrity of spermatozoa varies depending breed and species and preservation methods.

Before preservation the morphologically normal spermatozoa is similar to Danaa et al. [44]. They recorded $95 \%$ normal spermatozoa in rams before preservation. After chilling and freezing the rate of normal morphology of spermatozoa was decreased. Generally semen from most males contains some abnormally formed spermatozoa [45]. Beside this, breeding potential of a ram should have more than $70 \%$ morphologically normal sperm. In the present study the proportion of abnormal spermatozoa did not exceed $30 \%$ both for fresh and after chilling. The morphology of post thawed ram spermatozoa was also within the standard value [46]. Different factors may affect the morphology of spermatozoa e.g methods of preservation [47], age of the animal [48]. They recorded good quality sperm was found in 2-3 years rams after that decline gradually.

\section{Conclusions}

It would be concluded that the productive and reproductive performances of indigenous rams are satisfactory even though the body weight and scrotal circumference comparatively smaller than other breeds in the world. They attained to become puberty early with good libido scoring. The quality regarding volume, density and mass motility, concentration, motility, viability, functional integrity and normal morphology of semen were within the standard ranged published by others. The quality of semen from indigenous ram was also satisfactory after chilling up to $48 \mathrm{~h}$ and freezing. The others sexual behaviours were normal. Therefore, emphasis should be given to introduce $\mathrm{AI}$ in ewes using semen from indigenous rams to observe the success of fresh as well as preserved semen and increase sheep population with high genetic merit.

\section{Acknowledgements}

Authors thank to all personnel involved for their help in this work. The study was funded by Bangladesh Academy of Science and United State Department of Agriculture (BAS-USDA).

\section{References}

[1]. Bangladesh Economic Review, Financial System Management Unit (FSMU), Finance Division, Ministry of Finance, Government of the People's Republic of Bangladesh, 2013.

[2]. H.N. Turner, Origins of the CSIRO Booroola. In: Piper, L. R.; B. M. Bindon and R. D. Nethery (eds) The Booroola Merino. CSIRO, Australia, 1982, pp. 1-7.

[3]. FAO (Food and Agriculture Organization of the United Nations). Asian Livestock. Monthly Technical Magazine of the FAO. Animal Production and Health Commission for Asia and the Pacific (APHCA), 8, 1991, 85-87.

[4]. M. Kafi, M. Safdarian and M. Hashemi, Seasonal variation in semen characteristics, scrotal circumference and libido of Persian Karakul rams. Small Rumin. Res., 53, 2004, 133-139. 
[5]. R.B. Land and W.R. Carr, Testes growth and plasma LH concentration following hemicastration and its relation with female prolificacy in sheep. J. Reprod. Ferti., 45, 1975, 495.

[6]. A.A. Al-kawmani, M.M. Alfuraiji, F.M. Abou-Tarboush, M.A. Alodan and M.A. Farah, Developmental changes in testicular interstitium in the Najdi Ram Lambs. S. J. Bio. Sci., 21, 2014, 133-137.

[7]. A.M. Al-Ghalban, M.J. Tabbaa and R.T. Kridli, Factors affecting semen characteristics and scrotal circumference in Damascus bucks. Small Rumin. Res., 53, 2004, 141-149.

[8]. M.R. Hassan and M.A.I. Talukder, Comparative performance of different regional native sheep in Bangladesh. Bang. Vet., 28, $2011,85-94$.

[9]. J. Thompson and H. Meyer, Body condition scoring of sheep. Oregon State University Extension Service, USA, 1994

[10]. D.L. Foster, Puberty in the sheep. In the physiology of reproduction. $2^{\text {nd }}$ edition. E. Knobil and JD. Neil eds. Raven Press. Ltd. New York, 1994

[11]. S. Shankar and K.G. Mandal, Genetic and non-genetic factors affecting body weight of buffaloes. Vet. World. 3, 2010, 227-229.

[12]. M.J. Tabbaa, M.J. Kridli, R.T.A. Al-Ghalban and F.S. Barakeh, Age-related changes in scrotal circumference and some semen characteristics in Awassi rams. Anim. Reprod., 3(4), 2006, 431-438.

[13]. M.A. Snyman, W.J. Olivier, P.J. Griessel and J.A.N. Cloete, Growth and carcass characteristics of hair and wool type Dorper lambs under veld conditions in the Arid Karoo. November 25, 2010, http://gadi.agric.za/articles/Snyman_MA/growt_dorper_2002.php?

[14]. U. Younas, M. Abdullah, J.A. Bhatti, T.N. Pasha, N. Ahmad, M. Nasir and A. Hussain, Inter-relationship of body weight with linear body measurements In hissardale sheep at different stages of life. J. Anim. Sci., 23(1), 2013, 40-45

[15]. E. Mukasa-Mugerwa and Z. Ezaz, Relationship of testicular growth and size to age, body weight and onset of puberty in Menz ram lambs. Theriogenology, 38, 1992, 979-988.

[16]. S.A. Salhab, M. Zarkawi, M.F. Wardeh, M.R. Al-Masri and R. Kassem, Development of testicular dimensions and size, and their relationship to age, body weight and parental size in growing Awassi ram lambs. Small. Rumin. Resch., 40, $2003,187-191$.

[17]. A. Jibril, I.U. Ate, P.I. Rekwot and C.U. Osuhor, Effect of graded levels and sources of protein on scrotal circumference and semen profile of Yankasa rams. Sok. J. Vet. Sci., 9, 2011, 22-27.

[18]. S.W. Kochapakdee, S. Pralomkarn, S. Saithanoo, A. Lawpetchara and B.W. Norton, Aust. J. Anim. Sci., 7, 1994, 289.

[19]. N. Ahmad and D.E. Noakes, Sexual maturity in British breeds of goat kids. Br. Vet. J., 5, 1996, 93-103.

[20]. Z. Changjun, Puberty. Pathways to Pregnancy and Parturition, Sichuan Agricultural University, 2013

[21]. S. Schoenian, "Sheep 101". May3, 2014: < http://www.sheep101.info/201/ramrepro.html

[22]. G.D. Snowder, J.N. Stellflug and L.D. Van Vleck, Genetic correlation of ram sexual performance with ewe reproductive traits of four sheep breeds. Appl. Anim. Behev. Sci., 88, 2004, 253-261.

[23]. E.O. Price, Male sexual behavior, Vet. Clin. N. Ame. F. Anim. Prac. 3, 1987, 405-422.

[24]. P.L. Senger, Reproductive behavior. In: Senger PL (ed.), Pathways to Pregnancy and Parturition. Current Concepts Inc., Washington State University Research and Technology Park, Pullman, WA, USA, 2003, pp. 240-265.

[25]. L.M. Mitchell, M.J. Ranilla, G. Quintans, M.E. King, F. Gebbie and E.J.J. Robinson, Effect of diet and GnRH administration on post-partum ovarian cyclicity in autumn-lambing ewes. Anim. Reprod. Sci., 76, 2003, 67-79.

[26]. Azizunnesa, B.F. Zahora, F.Y. Bari and M.G.S. Alam, Effects of concentrate supplementation on reproductive performances and semen quality of indigenous rams in Bangladesh. J. Emb. Trans., 28(4), 2013325-335.

[27]. A. Perkins and C.E. Roselli, The Ram as a Model for Behavioral Neuroendocrinology, Horm. Behav., 52(1), 2007, 70-77.

[28]. G. Bermant, M.T. Clegg and W. Beamer, Copulatory behaviour of the ram, Ovis aries. I. A normative study. Anim Behav 17, 1969, 700-705.

[29]. R.L. Ax, M.R. Dally, B.A. Didon, R.W. Lenz, C.C. Love, D.D. Varner, B. Hafez and M.E. Bellin, Artificial Insemination. In: Hafez B, Hafez ESE, (Eds.): Reproduction in farm animals. (7th Eds.) Philadelphia, Lea and Febinger. 2000, pp. $376-389$.

[30]. M. Gundogun, Short term preservation of ram semen with different extenders, Afyon Kocatepe Üniversitesi Veteriner Fakültesi Dölermeve Sun'i Tohumlama Anabilim Dal. Res arti Afkas Univ vet fakderg 15, 2009, 429-435.

[31]. P.J.E. Hernández, R.F. Fernández, S.J.L. Rodríguez, R.E. Juárez, M.Y.G and Soto, R.A.D. García, Effect of cryopreservation of sheep semen related to its viability and acrosomal status. Rev. Salud. Anim., 34(2), 2012, 78-83.

[32]. M.G.G. Cunha, C.I.M. Gonzalez, F.F.R. Carvalho and A.T. Soares, Effect of diets containing whole cottonseed on the quality of sheep semen. On-line version. Acta. Sci. Anim. Sci. 34(3), 2012, http://dx.doi.org/10.4025/actascianimsci.v34i3.12963.

[33]. S.A. Ibrahim, Seasonal variations in semen quality of local and crossbred rams raised in the United Arab Emirates. Anim. Reprod. Sci., 49(2-3), 1997, 161-7.

[34]. T.A. Moss, D.R. Melrose, H.C.B. Reed and M. Vendeplasche, Spermatozoa semen and artificial insemination. In: JA, Laing (Ed) WJ, Brinley Morgan. Fertility and infertility in domestic animals. 4th ed. London, Balliere Tindall, 1988, pp.132-54.

[35]. J.J. Robinson, C.J. Ashworth, J.A. Rooke, L.M. Mitchell and T.G. McEvoy, Nutrition and fertility in ruminant livestock. Anim. F. Sci. Tech. 126, 2006, 259-276.

[36]. R.H. Foote, Factors Influencing The Quantity And Quality Of Semen Harvested From Bulls, Rams, Boars And Stallions. J. Anim. Sci., 47, 1978, 1-11.

[37]. M. Fernandez, F.J. Giralde, P. Frutos, P. Lavin and A.R. Mantecon, Effect of undegradable protein supply on testicular size, spermiogram parameters and sexual behavior of mature Assaf rams. Theriogenology, 62, 2004, 299-310.

[38]. D.L. Garner and E.S.E. Hafez, Spermatozoa and seminal plasma. In: Reproduction in farm animals (Ed) E.S.A. Hafez. Philadelphia, Lea and Febriger, 1982, pp. 12-17.

[39]. E.F. Grahman, M.K.L. Schmehl and D.S. Nelson, Problem with laboratory assays. Proc. 8th Tech. Con. Arti. Ins. Reprod NAAB, $1980,1-8$

[40]. E.G. Aisen, V.H. Medina and A. Venturino, Cryopreservation and post-thawed fertility of ram semen frozen in different trehalose concen-trations, Theriogenology, 57, 2002, 1801-1808.

[41]. K. Nilani, T. Eswaramohan and K. Balasubramaniam, Influence of temperature on motility and viability of bovine spermatozoa during cold storage. Int. J. Sci. Res. Pub., 2(12), 2012, 1-5.

[42]. N.L. Cross and S.E. Hanks, Effects of cryopreservation on human sperm acrosomes. Hum. Reprod., 6, 2011, 1279-83.

[43]. N.S. Juyena, Protein profiles and biochemical characteristics of semen: Influence on frozen-thawed spermatozoa quality in rams (Ovis Aries) and Alpacas (VicugnaAacos). PhD Thesis, Faculty of Veterinary Medicine, Department of Clinics Veterinary Science. University of Paduva, Italy, 2011, pp. 123-173.

[44]. N. Danaa, A. Tegegneb and T. Shenkorua, Feed intake, sperm output and seminal characteristics of Ethiopian highland sheep supplemented with different levels of leucaena (Leucaena leucocephala) leaf hay. Anim. F. Sci. Tech., 86, 2000, $239-249$. 
[45]. E.S.E. Hafez, Artificial insemination. In: ESE Hafez (editor) Reproduction in Farm Animals. pp 424-439. Lea and Febiger, Philadelphia, USA, 1993.

[46]. R. Kasimanickam, V. Kasimanickam, D. PelzerK and J.J. Dascanio, Effect of breed and sperm concentration on the changesin structural, functional and motility parameters of ram-lamb spermatozoa during storage at $4^{\circ} \mathrm{C}$. Anim. Reprod. Sci., 101, 2007, 6073.

[47]. S. Salamon and W.M.C. Maxwell, Storage of ram semen. Anim. Reprod. Sci., 62, 2000, 77-111.

[48]. I. David, L. Bodin, G. Lagriffoul, E. Manfredi and C. Robert-Granie, Character process model for semen volume in AI rams: evaluation of correlation structures for long and short term environmental effects. Gen. Sel. Evol. 39, 2007, 55-57. 